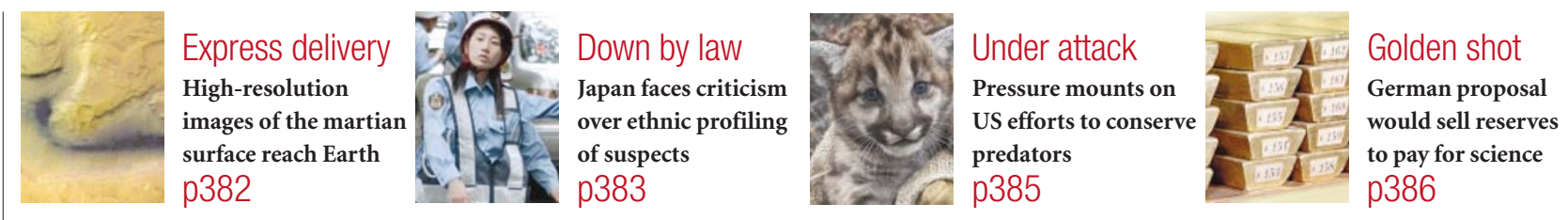

\title{
Prolific ecologist vows to fight Danish misconduct verdict
}

\section{Alison Abbott, Munich}

Denmark's main research misconduct body has ruled that Anders Pape Møller, one of the world's leading experts in behavioural ecology, is guilty of "scientific dishonesty".

Møller, a population biologist now at the Laboratory of Evolutionary Parasitology run by the CNRS, France's national research agency, at the Pierre and Marie Curie University in Paris, says that he is innocent and is appealing against the ruling.

The verdict was published last November on the website of the Danish Committees on Scientific Dishonesty (DCSD), but only circulated internationally after an English translation appeared last week on the website of the University of Copenhagen's Zoological Institute. It has rocked the tight-knit community of which Møller is part — he has been prolific in many areas of behaviour, evolution and ecology, and many of his findings are incorporated into standard textbooks.

"It will be a matter of no small consequence if a question mark appears over any part of Møller's work," says Chris Barnard, a behavioural ecologist at the University of Nottingham, UK, and president of the Association for the Study of Animal Behaviour (ASAB). Barnard says that he is waiting to see the outcome of Møller's appeal before deciding whether the ASAB should take any action. The society co-publishes the journal Animal Behaviour, which has carried several of Møller's papers.

The DCSD investigated an allegation brought in 2001 by Jørgen Rabøl, a former colleague at the Copenhagen institute, where Møller worked between 1994 and 1996. It concerns a paper testing whether herbivore activity causes asymmetry of new leaf growth in oak trees ${ }^{1}$. This is part of a large body of work by Møller suggesting that symmetry is an evolutionarily important signal of genetic quality - used by animals in mate choice, for example.

The paper was retracted by Møller in March 2001, with a note saying that "the measurements and analyses behind the data

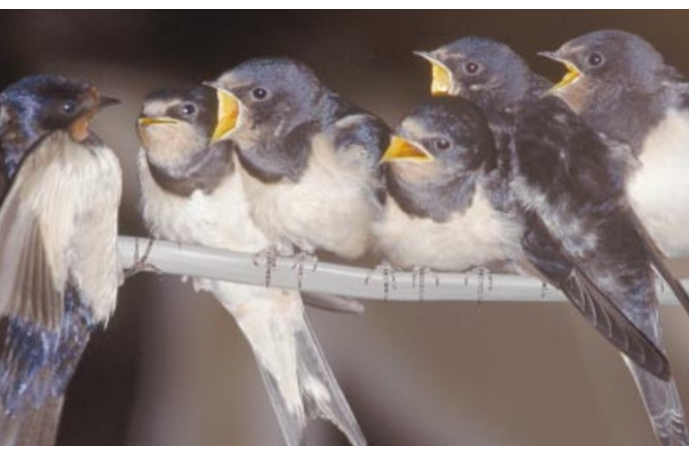

conduct allegations. It also claims that the technician involved was an alcoholic. Bo Vest Pedersen, director of the Copenhagen institute, disputes this last point.

Møller has been taken to task before by colleagues. In 1998, evolutionary biologist David Houle of Florida State University in Tallahassee criticized a book, Asymmetry, Developmental Stability and Evolution, coauthored by Møller. In a review in Evolution $^{3}$, Houle wrote that Møller had plagiarized a 200 -word section from another researcher's unpublished manuscript that he was reviewing.

A year later, evolutionary ecologist ... were flawed and misinterpreted" ${ }^{\prime 2}$. But Rabøl claimed that the wording of the retraction wrongly implied that a technician working with Møller had been to blame. He suspected that the technician's data had not been used in the paper, and filed a complaint to the DCSD.

\section{Data dispute}

The DCSD set up a three-person committee to investigate. Møller was unable to provide original data; instead he offered a transformed data set that he said corresponded to three tables in the paper. But the committee concluded that this could not have been based on authentic measurements in part because many data points were identical. "There are very strong indications that it must, at least in part, be fabricated," says the committee's report.

The report also notes that the original measurements submitted by the technician did not agree with the results reported in the paper, and so could not have been used. It says that Møller's reference in his retraction to flawed measurements is "hardly credible".

Even before the verdict Møller had filed a complaint with the Danish research ministry, claiming that one member of the investigating committee had a conflict of interest. Since the posting of the verdict in English, Møller has circulated this complaint by email to international colleagues. This note alleges that Rabøl had personal grudges against him, and a history of making mis-
Richard Palmer of the University of Alberta in Edmonton, Canada, wrote in The American Naturalist that Møller may have selectively published data to make his point ${ }^{4}$.

Some of Møller's co-authors are also aggrieved. Andrew Pomiankowski of University College London, who wrote four papers with Møller in the 1990s, says that he stopped working with him, suspecting unreliability. "If his name is on a paper, I will not read it," says Pomiankowski.

But Møller's supporters counter that critics are jealous of Møller's success and his vast publication record - he co-authored more than 100 papers between 2001 and 2003.

Møller says that he expects to be cleared by the ministry, but if not he vows to take his case to the courts or the Danish ombudsman. He notes that the DCSD last year landed in hot water after charging Bjørn Lomborg, author of a controversial book which claimed that environmentalists have exaggerated the threat to our planet, with dishonesty. That verdict was challenged by the Danish government (see Nature 427, 7; 2004).

Jean Clobert, former director of Möller's Paris lab, says that he is taking advice from the CNRS about how to respond. A second, CNRS-led, inquiry cannot be ruled out, he says.

Additional reporting by Rex Dalton.

1. Møller, A. P. \& de Lope, F. Oikos 82, 246-252 (1998).

2. Møller, A. P. \& de Lope, F. Oikos 92,558 (2001).

3. Houle, D. Evolution 52, 1872-1876 (1998).

4. Palmer, A. R. Am. Nat. 154, 220-233 (1999). 